\title{
The Formation of Polycode Text Theory
}

\author{
Natalia V. Novospasskaya*, Zou Huajing \\ Peoples' Friendship University of Russia (RUDN university) \\ 6, Miklukho-Maklaya str., Moscow, Russian Federation, 117198 \\ * Corresponding author: novospasskaya-nv@rudn.ru
}

\begin{abstract}
This review article is devoted to the theory of polycode texts that are represented as a combination of verbal and non-verbal components. This unity is supported by the meaning, structure and function, under which we mean the focus on solving a single communicative task. A polycode text includes signs of various semiotic systems, for example, colour and kinesics. A number of synonymous terminological descriptions of this phenomenon - creolized text, polycode text, polysemiotic text, semiotically enriched test indicates that we are currently witnessing the formation of the theory of polycode texts. Theoretical and terminological understanding of the object of our description occurs in such directions as the analysis of the components of polycode text and their correlation, description of methods and prospects for the study of polycode texts. The pragmatics of a polycode text, with a brief overview of the most notable works of Russian linguists, is considered in such main areas of its implementation as humorous polycode text and polycode text in cinematography. The most studied phenomenon in this direction is the description of the polycode text of advertising of various types. New directions of analysis are the description of the functioning of the polycode text in political linguistics and Internet communication. It is important to note the increase in the number of works that investigate the use of polycode text in school teaching and in teaching foreign languages. A new area of study of polycode text is its description as a reflection of the national linguistic picture of the world. This review is based on academic works, which are fundamental in this area of research, and also includes articles published in scientific journals in Russia over the past five years.
\end{abstract}

Keywords: polycode text, creolized text, verbal component, non-verbal component

\section{Article history:}

Received: 01.05.2020

Accepted: 08.02.2021

\section{For citation:}

Novospasskaya, N.V. \& Zou, Huajing. (2021). The Formation of Polycode Text Theory. RUDN Journal of Language Studies, Semiotics and Semantics, 12(2), 501-513. doi: 10.22363/2313-22992021-12-2-501-513

(C) Новоспасская Н.В., Цзоу Хуацзин, 2021

This work is licensed under a Creative Commons Attribution 4.0 International License https://creativecommons.org/licenses/by/4.0/ 
Удк 811.161.1:003

\title{
Становление теории поликодового текста
}

\author{
Н.В. Новоспасская", Цзоу Хуацзин \\ Российский университет дружбы народов \\ 117198, Российская Федерация, Москва, ул. Миклухо-Маклая, 6 \\ novospasskaya-nv@rudn.ru
}

\begin{abstract}
Аннотация. Обзор посвящен теории поликодовых текстов, которые представляют собой сочетание вербального и невербального компонентов. Данное единство поддержано смыслом, структурой и функцией, под которой мы понимаем направленность на решение единой коммуникативной задачи. Поликодовый текст включает знаки различных семиотических систем, например, цвет и кинессику. Наличие целого ряда синонимических терминологических описаний данного явления - креолизованный текст, поликодовый текст, полисемиотический текст, семиотически обогащенный тест - свидетельствует о том, что в настоящее время мы наблюдаем становление теории поликодовых текстов. Теоретическое, в том числе терминологическое осмысление объекта нашего описания, проходит в таких направлениях, как анализ компонентов поликодового текста и их связи, описание методов и перспектив исследования поликодовых текстов. Прагматика поликодового текста, с кратким обзором наиболее заметных работ российских лингвистов, рассмотрена в таких основных сферах его реализации, как юмористический поликодовый текст и поликодовый текст кинематографа. Наиболее изученным явлением в рассматриваемом направлении явлется описание поликодового текста рекламы различных типов. Новыми направлениями анализа является описание функционирования поликодового текста в политической лингвистике и интернет-коммуникации. Важно отметить увеличение количества работ, в которых исследуется использование поликодового текста в школьном обучении и в преподавании иностранных языков. Новой сферой изучения поликодового текста является его описание как отражение национальной языковой картины мира. Обзор выполнен на материале научных работ, которые являются основополагающими в данном направлении исследований, а также включает научные статьи, опубликованные в научных журналах России в течение последних пяти лет.
\end{abstract}

Ключевые слова: поликодовый текст, креолизованный текст, вербальный компонент, невербальный компонент

\section{История статьи:}

Дата поступления: 01.05.2020

Дата приема в печать: 08.02.2021

\section{Для цитирования:}

Novospasskaya N.V., Zou Huajing. The Formation of Polycode Text Theory // Вестник Российского университета дружбы народов. Серия: Теория языка. Семиотика. Семантика. 2021. T. 12. № 2. C. 501—513. doi: 10.22363/2313-2299-2021-12-2-501-513

\section{Introduction}

Modern linguistics holds interest in the description of texts that include visual and audio information, on the one hand, and the expansion of the range of phenomena and aspects of analysis, on the other. These complex texts are becoming more and more common in communication of various types, they are unequivocally 
assessed as the most successful and are often the only ones possible in the context of globalization rapprochement, which requires a universal and understandable language for communicants.

Sociologists and linguists point out the dominance of such means of communication as advertising, cinema, the Internet and television that are impossible without texts of a mixed nature. It is unambiguous to understand the tasks of this type of texts in maximizing the impact on recipients, providing information of a significant amount with small resource investments and implementing one or several secondary functions - emotive, aesthetic, orienting, educational, etc.

The purpose of this article is to describe the main approaches to the formation of a unified theory of polycode texts, features of its terminological support, and a description of the main directions of their study. V.V. Krasnykh explains the diversity of approaches, the plurality of descriptions and the multiplicity of definitions of the text by the fact that "the text itself, as a phenomenon of linguistic and extralinguistic reality, is a complex phenomenon: it is both a means of communication, and a way of storing and transmitting information, and a reflection of the mental life of an individual, and a product of a certain historical era, and the form of existence of culture, and the reflection of certain socio-cultural traditions, etc." [1. P. 205-206]. In full, this definition also refers to texts that combine the actual verbal component, any image and sound that are integrated, turning into a code. The decoding process combines the semantics of signs at all levels, thus transforming this type of information into a text of a higher order.

\section{Terminological shaping of the idea of a polycode text}

The history of the formation of the theory of polycode texts records the existence and, to varying degrees, active use of a number of terms describing the phenomenon under consideration. Some of these terminological units also include methodological approaches to describing the object of study itself. The nomination of a text: in which several codes interact, uses such terms as nonlinear text, creolized text, polysemiotic text, semiotically enriched text, polycode text.

The most common term is creolized text, first used by Yu.A. Sorokin and E.F. Tarasov: "Creolized texts are texts, the structure of which consists of two inhomogeneous parts: verbal (language/speech) and non-verbal (belonging to other sign systems than natural language)" [2. P. 180].

The term polycode text has been known since the 1970s, for example, G.V. Eiger and V.L. Yukht defined it as follows: "Cases of combining a natural language code with the code of a different semiotic system (image, music, etc.) should be classified as polycode texts in a broad semiotic sense" [3. P. 107].

A.G. Sonin describes a polycode text as a text built "on the connection in a single graphic space of semiotically heterogeneous components - a verbal text in oral or written forms of representation and signs of a different nature" [4. P. 117]. 
Researcher L.S. Bolshakova divides texts that combine elements of several types into linear — which can be perceived as "information in a row" and nonlinear, where she sees "a multidimensional network in which any point $<>$ is linked to any other point anywhere" [5. P. 20].

D.P. Chigaev, exploring ways to creolize an advertising text, uses a terminological-descriptive construction of a semiotically enriched text for the generic concept of inhomogeneous texts [6].

A.A. Bernatskaya proposes to consider the terms polycode text and polysemantic text as synonymous and writes about their preference "as a designation of a generic concept for inhomogeneous, syncretic messages (texts) formed by a combination of elements of sign systems, subject to their interdependence; it is advisable to keep the metaphorical and dynamic term creolization to indicate the degree of the very fact of participation of different semiotics elements in the text creation" [7. P. 106].

\section{Polycode text research direction}

The main areas of application of polycode text studies are:

1) polycode text in advertising, in political communication, humorous polycode text and polycode text in cinematography;

2) polycode text in Internet communication;

3) components of polycode text;

4) use of polycode text in teaching;

5) polycode text as a reflection of the national linguistic picture of the world.

\section{Polycode text in advertising}

A significant number of scientific works are devoted to the polycode advertising text, however, the extensive research material, the genre diversity of the research object and the constantly updated analysis material leaves this topic relevant. As an example, we consider such works as the studies of E.S. Kara-Murza [8], D.P. Chigaev [6; 9], E.N. Remchukova and V.A. Omelianenko [10], I.D. Romanova and I.V. Smirnova [11] and many others. Polycode text in political communication is represented primarily by the genres of political posters and political cartoons. These types of polycode text are described in the works by E.E. Anisimova [12], M.B. Voroshilova [13], N.M. Dugalich [14]; humorous polycode text was analyzed by Yu.S. Chaplygina [15]; polycode text of the film is described in the works by E.A. Krasina and E.S. Rybinok [16] and others.

\section{Polycode text in Internet communication}

Internet communication plays a significant role in social life, which is supported by the constantly growing number of users and the development of new technologies for network interaction. Internet communication has a number of characteristic 
features, under which researchers O.I. Maksimenko [17], I.V. Bugaeva [18], L.V. Babina [19], Y.V. Schurina [20], D.S. Michurin [21] and many others understand hypertextuality, depersonification, interactivity, polycode character. The special character of the polycode text is described through increasing the role of the actual iconic signs both in the information field and in the speech produced.

The subject of linguistic research of polycode text in Internet communication is linguistic means, pragmatic potential of polycode text, their types and structural specificity and features of functioning. Internet communication is also distinguished by the creation of new genres, for example, Internet memes, the polycode nature of which is considered in the works by Y.V. Schurina [20] and many others; demotivators $[18 ; 19]$. These genres are characterized by the lack of clarity of the addressee, they perform communicative, aesthetic, axiological and expressive functions.

\section{Polycode text components and their correlation}

An important characteristic describing a polycode text is its integrity. This characteristic is set, first of all, by the communicative and cognitive attitudes of the authors of the text, a single theme, a chosen stylistic and compositional solution, and a single visual, semantic and functional whole, which is formed by combining the resources of the verbal and iconic levels.

Traditionally, they distinguish verbal and iconic components of a polycode text, which is probably associated with the maximum information load that a person's organs of sight and hearing have: "The largest part of socially significant, rich and essential for society sign systems is focused on perception through vision" [22. P. 323]. In this regard, R. Bart considered polycode texts related to mass communication to be the most sophisticated: "In television, cinema, advertising, the emergence of meanings depends on the interaction of images, sound and the style of icons" [23. P. 124]. R. Bart divides the text of advertising by the nature of the content and representation in literal (visually uncoded), symbolic (visually coded) and linguistic forms. The connection of these components forms the complex meaning of a polycode text [23. P. 303].

There are several approaches to the classification of polycode text elements, which are most often called verbal (and thus retain a semantic connection with the text) and averbal, which include images (photographs and drawings) and additional elements (conventional designations, for example, symbols or drawings within a word, and also paralinguistic means - font design, lines, frames, etc.).

During the formation of the polycode text theory, the variability of terms in the nomination of elements of a polycode text was expressed in pairs averbal - iconic; paralinguistic - iconic; paralinguistic — paragraphemic. Currently, the use of the terms iconic and averbal remains parallel. M.B. Voroshilova believes that "it is terminologically challengeable to use the term iconic component when analyzing creolized texts as an equivalent, identical replacement for the designation of a 
graphic component" [13. P. 76]. This is due to the presence of a general orientation of the text towards iconicity, which has been repeatedly emphasized by researchers [see 24 P. 119]. Also, the use of the term visual in relation to the iconic component is not justified, since the text in writing is also visual, so M.B. Voroshilova considers it appropriate to use the dichotomy of the verbal - non-verbal components of the polycode text.

Paragraphemic means are understood as elements of a written text that accompany the verbal component and express various connotations (M.G. Shvetsova [25], Yu.A. Eykalis [26]). M.G. Shvetsova divides paragraphemic means into those that are tied to the verbal component of the polycode text, tied to the verbal means of the text; elements that organize content and have special functions in the text [25]. This division corresponds to the classification by N.N. Bolshakova, who stresses out topographemic means, under which the author sees the planar variation of the text, supragraphemic means, i.e. font variation and singrahemic means (artistic and stylistic variation of punctuation marks). These elements are considered important and make it possible to increase the implicitness of the text [5].

A.N. Baranov and L.B. Parshin, relying on the mechanism of creating paragraphemic means, divide them into topographemic means - variation of fonts in a plane; supragraphemic means - choice of the actual font size, its type, use of spaces and singraphemic means - non-standard use of punctuation marks to express the author's intention [27. P. 38]. Supragraphemic means also include variation within type faces and the choice of background and colour, use of bulleted lists, and integration into the text of elements belonging to other language system [28. P. 149-150].

Yu.A. Eykalis, analyzing the polycode text of comics in German, notes the widespread use of topographemic (planar variation of fonts), supragraphemic (font variation) and singrahemic means (understands them as artistic and stylistic variation of punctuation marks) and their various combinations, explaining this by the information density of the comic text and its pragmatic potential. The set of these means of a polycode text, according to the author, serves to form speech portraits of comic book heroes, partially realize the aesthetic function [26].

E.E. Anisimova divides the degree of cohesion of the components of a polycode text into texts with partial creolization (relative autonomy of the verbal and averbal parts, for example, when the iconic component is a secondary element) and full creolization (cohesion of components), emphasizing the difference in the need for the iconic component to participate in the polycode text, for example, a poster or an advertising image with text.

The researcher of a polycode text O.V. Poimanova, who calls the object of research a video-verbal text, suggests classifying these texts by the nature of the iconic component. Static video-verbal text, such as political cartoons or magazine advertisements, is contrasted with dynamic video-verbal text, such as a film or a video advertisement). The classification of the verbal component is a division into an oral format (live speech or recorded live speech) and a written one [29]. 


\section{Use of polycode text in teaching}

The use of polycode text in teaching is a promising area of research: "No one involved in language teaching can afford to ignore the huge range of opportunities and challenges opened up by technology" [30. P. 109]. The main attention of the authors is paid to the creation and selection of polycode texts, which should combine the unambiguous iconic component and elements of the verbal component adequate to the task in hand. The intention of the authors of the polycode text should coincide with the organizational, motivational, communicative, substantive aspects of the lesson, not distract the student from the set methodological tasks and complement the lesson materials informationally and axiologically. Currently, we can observe published works that provide general recommendations and describe the experience in teaching certain disciplines of Russian as a foreign language for certain levels and languages. T.S. Kyst [31] examines the questions of hypertextuality and creolization of texts of electronic textbooks.; O.A. Senatorova sees the prospects for work in the field of creating educational materials for teaching the Russian language to foreigners "in a deeper study of issues related to the linguodidactic analysis of Russian linguistic culture, followed by the selection of the most valuable realities for cultural activities", which is impossible without the involvement of polycode texts [32. P. 323]. I.A. Koltsov [33] proposed a method of using a polycode text in the study of a foreign language in the aspect of intercultural communication. V.A. Sentsova considers polycode texts as a means of teaching Russian grammar to Italian native speakers at the beginner level [34]. N.V. Perfilieva and her co-authors propose forms of working with polycode text at different levels of learning Russian as a foreign language [35]. The team of authors S.A. Leppik, A.Y. Ustinov and T.A. Chabanets describe the implementation of polycode text in school textbooks as an irrevocable condition of the principle of visibility - an approach that "involves the translation of the task formulation by direct observation of the subject of speech using certain channels of sensory perception" [36. P. 451].

\section{Polycode text as a reflection of the national linguistic picture of the world}

It is known that material and spiritual culture is reflected in the language, which has an internal form specific to each language. Language has a national character, which is reflected in it through special forms of representing the world. Language is "a mediating link between a person and the world around" [37. P. 237-238]. These ideas are expressed in a polycode text both intentionally and implicitly. Linguists such as E.S. Kara-Murza [8], N.V. Danilevskaya [38], E.N. Remchukova, V.A. Omelianenko [10], E.P. Garan [39], E.E. Anisimova [40], E.M. Aleksandrova [41] and many others reveal this topic in their works. Thus, the classification of elements of linguocultural information in a polycode text, for example, advertising [42; 43], includes physical and geographical characteristics of a country; 
description of external features of a nation, which consists of such elements as national costume, household items, features of everyday clothing, etc. An important aspect of a polycode text is the appeal to cultural and historical material values of a nation. These are, first of all, architectural monuments, monuments dedicated to national heroes, unusual architectural solutions that create the appearance of modern cities, etc. The theme of opposing national and foreign comes close to the value priorities of a nation. Numerous advertising examples confirm that the polycode text contains various elements that form a single conceptual idea that consists in the presentation of one's own cultural values taking into account national components of other cultures [44. P. 132].

\section{Polycode text: research methods and perspectives}

Research methods of a polycode text are inextricably linked with the aspects of its description. Following M.B. Voroshilova [13. P. 75-80] researchers highlight the description of the structure of a polycode text, correlation of its components, semiotic codes and their representation in a specific text, linguistic resources involved in the verbal component. Let us consider the algorithm for analyzing a polycode text presented in the works by N.M. Dugalich [14]:

1) discussion of the pragmatics of the polycode text with the identification of its occasion, personalities, and precedent basis;

2) description of the visual means of the polycode text, which is associated with the analysis of the compositional and stylistic solutions, and genre originality of the image;

3) semiotics of the polycode text, which is understood as the analysis of the use of colour codes and kinesics;

4) paragraphemic means used in a specific example of the polycode text;

5) verbal level - assessment of the text component (its translation, if the text is performed in a foreign language); compositional and structural organization; dialectal and expressive language means; language game; correlation of text and images;

6) allusive and precedent components; hidden resources of the polycode text;

7) interconnection of the iconic and verbal components of the polycode text is thought over.

Polycode text research perspective consists, in our opinion, in carrying out comparative and contrastive works on the description of texts of a certain genre orientation, performed in different languages; description of new genres of a polycode text and its intertextual component. The origination of new objects of this type of texts will allow receiving material for describing, comparing and supplementing existing typologies and directions in the future.

\section{References}

1. Krasnykh, V.V. (2001). Fundamentals of Psycholinguistics and Communication Theory. Course of lectures. Moscow: Gnosis. (In Russ.).

2. Sorokin, Yu.A. \& Tarasov, E.F. (1990). Creolized Texts and Their Communicative Function. Speech Effect Optimization. Moscow, Vysshaya shkola Publ. pp. 180-186. (In Russ.). 
3. Eiger, G.V. \& Yukht, V.L. (1974). The Construction of a Typology of Texts In Text linguistics: proceedings of the scientific conference at Moscow State Pedagogical Institute of Foreign Languages named after M. Torez: in 2 p. P. I. Moscow. pp. 103-109. (In Russ.).

4. Sonin, A.G. (2005). Experimental Studies of Multimodal Text Comprehension: Main Directions. Voprosy Jazykoznanija, 6, 115-123. (In Russ.).

5. Bolshakova, L.S. (2008). On the Content of the Concept of "polycode text" // Bulletin of Samara State University, 4, 19-24. (In Russ.).

6. Chigaev, D.P. (2010). Methods of Creolization of a Modern Advertising Text [dissertation]. Moscow. (In Russ.).

7. Bernatskaya, A.A. (2000). On the Problem of Text Creolization: History and the state-of-arts. Speech communication: a specialized bulletin, 3 (11), 104-110. (In Russ.).

8. Kara-Murza, E.S. (2001). "Brave new world" of Russian Advertising: Socio-cultural, stylistic and cultural-speech aspects In Dictionary and culture of Russian speech. To the 100th anniversary of the birth of S.I. Ozhegov. Moscow: Indrik. pp. 165-186. (In Russ.).

9. Chigaev, D.P. (2008). Creolized Lexeme. Bulletin of the Moscow Region State University. Series: Russian Philology, 2. 82-85. (In Russ.).

10. Remchukova, E.N. \& Omelianenko, V.A. (2017). Linguistic Means of Russia’s Image Making in Modern Advertisinge. RUDN Journal of Language Studies, Semiotics and Semantics, 8(2), 341-349. (In Russ.).

11. Romanova, I.D. \& Smirnova, I.V. (2019). Persuasive Techniques in Advertising. Training, Language and Culture, 2019.3(2), 55-70. DOI: 10.29366/2019tlc.3.2.4.

12. Anisimova, E.E. (1994). Communicative-pragmatic Norms of German Appellate Texts [dissertation]. Moscow. (In Russ.).

13. Voroshilova, M.B. (2007). A Creolized Text: Aspects of studying. Political Linguistics, 1(21), 70-80. (In Russ.).

14. Dugalich, N.M. (2020). Universal and Culturally Specific Features and Linguistic Peculiarities of the Political Cartoon in the Arabic and French Languages. RUDN Journal of Language Studies, Semiotics and Semantics, 11(3), 479-495. DOI: 10.22363/2313-2299-2020-11-3-479-495.

15. Chaplygina, Yu.S. Text Categories of Linguo-visual Phenomenon Charicatures [Electronic resource]. URL: http://main.isuct.ru/files/konf/antropos/SECTION/3/chaplygina.htm (accessed: 10.01.2021). (In Russ.).

16. Krasina, E.A., Rybinok, E.S. \& Moctar, A. (2020). Film Naming: Book Titles and Film Titles. RUDN Journal of Language Studies, Semiotics and Semantics, 11(2), 330-340. DOI: $10.22363 / 2313-2299-2020-11-2-330-340$.

17. Maksimenko, O.I. (2012). Polycode VS. Creolized Text: Terminology problems. RUDN Journal of Language Studies, Semiotics and Semantics, 2, 93-102. (In Russ.).

18. Bugaeva, I.V. Demotivators as a new genre in Internet communications: genre signs, functions, structure [Electronic resource]. URL: http://www.rastko.rs/filologija/stil/2011/10Bugaeva (accessed: 01.05.2021). (In Russ.).

19. Babina, L.V. (2013). On Features of Demotivators as Polymodal Text. Philology. Theory \& Practice, 2 (20), 28-33. (In Russ.).

20. Schurina Y.V. (2014). Internet Memes in the Structure of Comic Speech Genres. Speech Genres, 1-2(9-10), 147-153. DOI: 10.18500/2311-0740-2014-1-2-9-10-147-153. (In Russ.).

21. Michurin, D.S. (2013). Impact of Multimodal Texts on the ways of Self-presentation in Virtual Internet-based Communication. Vestnik Tverskogo gosudarstvennogo universiteta. Serija "Filologija", 5(2), 320-326. (In Russ.).

22. Jacobson, R.O. (1985). Language in relation to Other Communication Systems. In: Selected works. Moscow: Nauka. (In Russ.).

23. Bart, R. (1994). Selected works. Semiotics. Poetics. Moscow: Progress. (In Russ.).

24. Sigal, K.Ya. (1997). The Problem of Iconicity in Language (a survey of literature). Voprosy Jazykoznanija, 6, 100-120. (In Russ.). 
25. Shvetsova, M.G. Paralinguistic Means in Text Linguistics [Electronic resource] LingvoMaster. URL: http://www.lingvomaster.ru/files/210.pdf (accessed: 03.01.21).

26. Eykalis, Yu.A. (2015). Paralinguistic Means of Communication in the Texts of Modern German-language Comics. Vestnik of the Orenburg State University, 11, 135-141. (In Russ.).

27. Baranov, A.N. (1989). Influencing Potential of Variation in the field of Metagraphics. In: Problems of the effectiveness of speech communication: collection of articles, A.N. Baranov, L.B. Parshin (eds.). Moscow. (In Russ.).

28. Kochetova, L.A. (2008). Hypertextual Structure and Printed Advertising Text. Science Journal of Volgograd State University. Linguistics, 2(8), 147-151. (In Russ.).

29. Poimanova, O.V. (1997). The Semantic Space of the Video Verbal Text: PhD thesis in Philological sciences [dissertation]. Moscow. (In Russ.).

30. Rogers, P. (2017). Digital Language Learning and Teaching: Research, theory and practice (a review). Training, Language and Culture, 1(3), 104-109. doi: 10.29366/2017tlc.1.3.7.

31. Kyst, T.S. (2008). About Hypertextuality and Creolization of Texts of Electronic Textbooks. Philology. Theory \& Practice, 2 (2), 62-65. (In Russ.).

32. Senatorova, O.A. (2020). A Coursebook on Linguocultural Studies for Foreigners studying the Russian language: Concept and Content. Russian Language Studies, 18(3), 315-327. DOI: 10.22363/2618-8163-2020-18-3-315-327. (In Russ.).

33. Koltsov, I.A. (2009). The Method of Using Creolized Hypertext in Teaching Intercultural Foreign Language Communication among Students of a Language University [dissertation]. Saint Petersburg. (In Russ.).

34. Sentsova, V.A. (2017). The Use of the Linguodidactical Potential of Multicode Texts in Teaching Italian students to a Russian Grammar. Modern Science: actual problems of theory and practice, 8, 170-172. (In Russ.).

35. Novospasskaya, N., Zou, Huajing, Perfilieva, N. \& Lazareva, O. (2019). Innovative method of teaching based on polycode texts. In: Edulearn19 Proceedings (11th International Conference on Education and New Learning Technologies, 1-3 July, 2019, Spain). Palma. pp. 4524-4528. DOI: 10.21125/edulearn.2019.1132.

36. Leppik, S.A., Ustinov, A.Y. \& Chabanets, T.A. (2019). Event-driven Approach to teaching Russian to schoolchildren of the Russian Ministry of Foreign Affairs. Russian Language Studies, 17(4), 445-459. doi: 10.22363/2618-8163-2019-17-4-445-459.

37. Maslova, V.A. (2019). The Role of a Language in the World's Conceptualization: the Aspect of Cultural Linguistics. Russian Language Studies, 17(2), 184-197. doi: 10.22363/26188163-2019-17-2-184-197. (In Russ.).

38. Danilevskaya, N.V. (2012). On Specific Character of Texts of Social Advertisement in Contemporary Advertisement Discourse (based on the data of medical prophylactic literature). Perm University Herald. Russian and Foreign Philology, 4(20), 132-137. (In Russ.).

39. Garan, E.P. (2018). The Advertising Slogan as a Special Marker of Advertisement Language. Actual issues of modern philology and journalism, 2(29), 133-136. (In Russ.).

40. Anisimova, E.E. (2003). Linguistics of the Text and Intercultural Communication (based on creolized texts). Moscow: Academy. (In Russ.).

41. Aleksandrova, E.M. (2018). A Creolized Language Game as a Semiotic Phenomenon. Philology. Theory \& Practice, 3(81), 276-282. DOI: 10.30853/filnauki.2018-3-2.15. (In Russ.).

42. Zou, Huajing \& Novospasskaya, N.V. (2021). Classification of Elements of Linguocultural Information in the Polycode Text of Printed Advertising based on the material of the Russian and Chinese Languages. Litera, 2, 1-10. DOI: 10.25136 / 2409-8698.2021.2.35001. (In Russ.).

43. Terskikh, M.V. (2012). Polycode Mechanisms of Metaphorization in Advertising. Bulletin of the Leningrad State University named after A.S. Pushkin (Vestnik Leningradskogo gosudarstvennogo universiteta imeni A.S. Pushkina), 2 (7), 162-172. (In Russ.).

44. Kuryanovich, A.V. \& Dragunayte, A.V. (2015). Place and Role of Visual Language in Modern Communication (illustrated creolized advertising texts). Tomsk State Pedagogical University Bulletin, 4, 153-159. (In Russ.). 


\section{Библиографический список}

1. Красных B.B. Основы психолингвистики и теории коммуникации : курс лекций. М.: Гнозис, 2001.

2. Сорокин Ю.А. Тарасов Е.Ф. Креолизованные тексты и их коммуникативная функция // Оптимизация речевого воздействия. М., 1990. С. 178-187.

3. Ейгер Г.В., Юxт В.Л. К построению типологии текстов // Лингвистика текста: материалы научной конференции в МГПИИЯ им. М. Тореза. Ч. 1. М., 1974. С. 103-109.

4. Сонин А.Г. Экспериментальное исследование поликодовых текстов: основные направления // Вопросы языкознания. 2005. № 6. С. 115-123.

5. Большакова Л.С. О содержании понятия «поликодовый текст» // Вестник СамГУ. 2008. № 4. C. $19-24$.

6. Чигаев Д.П. Способы креолизации современного рекламного текста: дис. ... канд. филол. наук. М., 2010.

7. Бернацкая A.A. К проблеме «креолизации» текста: история и современное состояние // Речевое общение: Специализированный вестник под редакцией А.П. Сковородникова. Красноярск, 2000. Вып. 3 (11). С. 104-110.

8. Кара-Мурза Е.С. «Дивный новый мир» российской рекламы: социокультурные, стилистические и культурно-речевые аспекты // Словарь и культура русской речи. К 100-летию со дня рождения С.И. Ожегова. М.: Индрик, 2001. С. 165-186.

9. Чигаев Д.П. Креолизованная лексема // Вестник МГОУ. Серия «Русская филология». 2008. № 2. С. $82-85$.

10. Ремчукова E.Н., Омельяненко В.А. Языковые средства формирования имиджа России в современной рекламе // Вестник Российского университета дружбы народов. Серия: Теория языка. Семиотика. Семантика. 2017. T. 8. № 2. С. 341-349. DOI: 10.22363/23132299-2017-8-2-341-349.

11. Romanova I.D., Smirnova I.V. Persuasive techniques in advertising // Training, Language and Culture. 2019. № 3(2). P. 55-70. DOI: 10.29366/2019tlc.3.2.4.

12. Анисимова E.E. Коммуникативно-прагматические нормы немецких аппелятивных текстов: дис. ... д-ра филол. наук. М., 1994.

13. Ворошилова М.Б. Креолизованный текст: аспекты изучения // Политическая лингвистика. 2007. № 1(21). С. 75-80.

14. Dugalich N.M. Universal and Culturally Specific Features and Linguistic Peculiarities of the Political Cartoon in the Arabic and French Languages // RUDN Journal of Language Studies, Semiotics and Semantics. 2020. 11(3). P. 479-495. DOI: 10.22363/2313-2299-2020-11-3-479-495.

15. Чапльгина Ю.С. Юмористические креолизованные тексты: структура, семантика, прагматика: на материале английского языка: дис. ... канд. филол. наук. Самара, 2002.

16. Krasina E.A., Rybinok E.S., Moctar A. Film Naming: Book Titles and Film Titles // RUDN Journal of Language Studies, Semiotics and Semantics. 2020. № 11(20). P. 330 -340. DOI: 10.22363/2313-2299-2020-11-2-330-340.

17. Максименко О.И. Поликодовый vs. креолизованный текст: проблема терминологии // Вестник Российского университета дружбы народов. Серия: Теория языка. Семиотика. Семантика.2012. № 2. С. 93-102.

18. Бугаева И.В. Демотиваторы как новый жанр в Интернет-коммуникации: жанровые признаки, функции, структура, стилистика [Электронный ресурс]. Режим доступа: http://www.rastko.rs/filologija/stil/2011/10Bugaeva (дата обращения: 05.01.2021).

19. Бабина Л.В. Об особенностях демотиватора как полимодального текста // Филологические науки. Вопросы теории и практики. 2013. № 2 (20). С. 28 -33.

20. Щурина Ю.В. Интернет-мемы в структуре комических речевых жанров // Жанры речи. 2014. № 1-2(9-10). C. 147-153. DOI: 10.18500/2311-0740-2014-1-2-9-10-147-153.

21. Мичурин Д.С. Роль поликодовых текстов в самопрезентации участников интернет-сообщества // Вестник Тверского государственного университета. Серия «Филология». 2013. № 5. Выпуск 2. С. 320 - 326 . 
22. Якобсон Р.О. Язык в отношении к другим системам коммуникации // Избранные работы. М.: Наука, 1985.

23. Барт Р. Избранные работы. Семиотика. Поэтика. М.: Прогресс, 1994.

24. Сигал К.Я. Проблемы иконичности в языке (обзор литературы) // Вопросы языкознания. 1997. № 6. С. $100-120$.

25. Швецова М.Г. Паралингвистические средства в лингвистике текста [Электронный ресурс] // LingvoMaster. Режим доступа: http://www.lingvomaster.ru/files/210.pdf (дата обращения: 03.01.21).

26. Ейкалис Ю.А. Паралингвистические средства коммуникации в текстах современных немецкоязычных комиксов // Вестник Оренбургского университета. 2015. № 11. С. 135-141.

27. Баранов А.Н. Воздействующий потенциал варьирования в сфере метаграфемики // А.Н. Баранов, Л.Б. Паршин. Проблемы эффективности речевой коммуникации: сб. научноаналитических обзоров. М., 1989.

28. Кочетова Л.А. Печатный рекламный текст как гипертекстовая структура // Вестник Волгоградского государственного университета. Языкознание. 2008. № 2(8). С. 147-151.

29. Пойманова О.В. Семантическое пространство видеовербального текста: дис. ... канд. филол. наук. М., 1997.

30. Rogers $P$. Digital language learning and teaching: Research, theory and practice (a review) // Training, Language and Culture. 2017. № 1(3). P. 104-109. DOI: 10.29366/2017tlc.1.3.7.

31. Куст T.C. О гипертекстуальности и креолизованности текстов электронных учебных пособий // Филологические науки. Вопросы теории и практики. 2008. № 2 (2). С. $62-65$.

32. Сенаторова O.A. Учебно-практическое пособие по лингвокультурологии для иностранцев, изучающих русский язык: концепция и содержание // Русистика. 2020. № 18(3). C. 315-327. DOI: 10.22363/2618-8163-2020-18-3-315-327.

33. Кольцов И.А. Методика использования креолизованных гипертекстов в обучении межкультурному иноязычному общению студентов языкового вуза. Автореф. дисс. ... канд. пед. наук. СПб., 2009.

34. Сенцова B.A. Использование лингводидактического потенциала поликодовых текстов при обучении итальянских учащихся русской грамматике // Современная наука. Актуальные вопросы теории и практики. Серия «Гуманитарные науки». 2017. № 8. С. 170-172.

35. Novospasskaya N., Zou Huajing, Perfilieva N., Lazareva O. Innovative method of teaching based on polycode texts // Edulearn19 Proceedings (11th International Conference on Education and New Learning Technologies, 1-3 July, 2019, Spain). Palma, 2019. pp. 4524 4528. DOI: $10.21125 /$ edulearn.2019.1132.

36. Леппик С.А., Устинов А.Ю., Чабанец Т.А. Событийный подход к усвоению русского языка учащимися заграншкол Министерства иностранных дел России // Русистика. 2019. T. 17. №4. C. 445-459. DOI: 10.22363/2618-8163-2019-17-4-445-459.

37. Маслова В.A. Роль русского языка в концептуализации мира: лингвокультурный аспект // Русистика. 2019. Т. 17. № 2. С. 184 -197. doi: 10.22363/2618-8163-2019-17-2-184-197.

38. Данилевская Н.В. О специфике текстов социальной рекламы в современном рекламном дискурсе (на материале медицинской профилактической литературы) // Вестник Пермского университета. Российская и зарубежная филология. 2012. № 4(20). С. 132-137.

39. Гаран Е.П. Рекламный слоган как особый маркер языка рекламы // Актуальные вопросы современной филологии и журналистики. 2018. № 2 (29). С. 133-136.

40. Анисимова E.E. Лингвистика текста и межкультурная коммуникация (на материале креолизованных текстов). М.: Академия, 2003.

41. Александрова E.M. Креолизованная языковая игра как семиотический феномен // Филологические науки. Вопросы теории и практики. 2018. № 3(81). C. 276-282. DOI: 10.30853/filnauki.2018-3-2.15.

42. Цзоу Хуацзин, Новоспасская Н.В. Классификация элементов лингвокультурологической информации в поликодовом тексте печатной рекламы на материале русского и китайского языков // Litera. 2021. № 2. C. 1-10. DOI: 10.25136/2409-8698.2021.2.35001. 
43. Терских М.В. Поликодовые механизмы метафоризации в рекламе // Вестник Ленинградского государственного университета им. А.С. Пушкина. 2012. № 2 (Т. 7). С. 162-172.

44. Курьянович А.В., Драгунайте А.В. Место и роль визуального языка в современной коммуникации (на примере креолизованных рекламных текстов) // Вестник Томского государственного педагогического университета. 2015. № 4. С. 153-159.

\section{Information about the authors:}

Natalia V. Novospasskaya, PhD in Philology, Associate Professor of the General and Russian Linguistics Department, Philological faculty, Peoples' Friendship University of Russia (RUDN University); e-mail: novospasskaya-nv@rudn.ru; ORCID 0000-0001-7599-0246.

Zou Huajing, PhD student of the General and Russian Linguistics Department, Philological faculty, Peoples’ Friendship University of Russia (RUDN University); e-mail: 1042188017@rudn.ru.

\section{Сведения об авторах:}

Новоспасская Наталья Викторовна, кандидат филологических наук, доцент кафедры общего и русского языкознания филологического факультета Российского университета дружбы народов; e-mail: novospasskaya-nv@rudn.ru; ORCID 0000-0001-7599-0246.

Цзоу Хуадзин, аспирант кафедры общего и русского языкознания филологического факультета Российского университета дружбы народов; e-mail: 1042188017@rudn.ru. 